\title{
Pemikiran Abdullah Ahmed An-Naim tentang Dekontruksi Syari'ah sebagai Sebuah Solusi
}

\author{
Ahmad Taufiq \\ UIN Maulana Malik Ibrahim Malang \\ E-mail:ahmadtaufiq982@gmail.com
}

\begin{abstract}
The laws contained in the Qur'an still exist that require interpretation and have the potential to develop. Muslims worldwide may be entitled to apply Islamic law, provided it does not violate the rights of other people and groups, both within and outside of the Islamic community. That is, in claiming and using individual and collective rights to self-determination, Muslims must also recognize and guarantee equal rights for others. Abdullah, descriptive-analytical nature. Ahmed An-Naim to answer the gap between shariah and issues of modernity. Sharia decontructions are used for Islamic legal issues using the Knife of Analysis used first by Mahmud Thaha's Theory of Law Evolution, the second nasikh mansukh theory, the third Makiyyah and Madaniyah, the fourth the interpretation of the gender-based text, the fifth concept of shari'a on human rights.
\end{abstract}

Keywords : Law, Dekontruksi Syariah, Teory of Evolution, Concepts

\begin{abstract}
ABSTRAK
Hukum yang terkandung di dalam al-Qur'an, masih ada yang memerlukan penafsiran dan mempunyai potensi untuk berkembang. Umat Islam sedunia boleh saja (berhak) menerapkan hukum Islam, asal tidak melanggar hak orang dan kelompok lain, baik di dalam maupun di luar komunitas Islam. Artinya, dalam mengklaim dan menggunakan hak-hak perorangan dan kolektif untuk menentukan nasib sendiri, kaum muslimin juga harus mengakui dan menjamin hak-hak yang sama bagi orang lain. Abdullahi Ahmed An-Naim untuk menjawab kesenjangan antara syariah dan isuisu modernitas. Dekontruksi syariah digunakan untuk permasalahan hukum Islam dengan menggunakan pisau analisis yang dipakai pertama Teori Evolusi Hukum Mahmud Thaha, kedua Teori nasikh mansukh, ketiga
\end{abstract}


Makiyyah dan Madaniyah keempat, Pemaknaan teks berbasis gender, kelima Konsep syariah terhadap Hak Asasi Manusia.

Kata Kunci : Hukum, Dekontruksi Syari’ah, Teori Evolusi, Konsep

\section{Pendahuluan}

Al-Qur'an pada mulanya diwahyukan sebagai respon terhadap situasi masyarakat saat itu, yang kemudian tumbuh dan berkembang lebih luas lagi. Hukum-hukum yang terkandung di dalam al-Qur'an itu pun, masih ada yang memerlukan penafsiran dan mempunyai potensi untuk berkembang. Jika pada masa Rasulullah SAW, dalam memahami ayat-ayat semacam itu, penjelasan diberikan langsung oleh beliau dengan sunnahnya. Akan tetapi, pada masa berikutnya, ketika beliau sudah wafat dan masyarakat Islam mengalami perkembangan pesat, serta wilayah kekuasaan Islam semakin luas, penjelasan itu dilakukan oleh para sahabat (Lahmuddin Nasution 2001, 4). Islam diyakini sebagai agama yang universal tidak terbatas pada ruang dan waktu tertentu. Al-Qurān sendiri menyatakan bahwa ajaran Islam berlaku untuk seluruh umat manusia. Oleh karena itu Islam seharusnya dapat diterima oleh setiap manusia. Karena agama Islam itu sendiri dapat berhadapan dengan masyarakat modern, sebagaimana ia dapat berhadapan dengan tantangan modernitas, dan agama Islam dituntut dapat menghadapi tantangan moderenitas perlu dijelaskan tentang sifat dan ajaran Islam (Mahmoud Mohamed Taha 1987, 5).

Muhammad Taha membedakan antara term Islam dan syariah. Menurutnya, Islam adalah sebuah ketundukan dan kepasrahan secara total dan meyakini Allah sebagai Tuhan. Adapun syariah bukanlah Islam itu sendiri melainkan hanyalah interpretasi terhadap teks/nash yang dipahami melalui konteks historis tertentu. Konsekuensi logis dari pemahaman tersebut adalah suatu kesalahan besar jika menerapkan syariah yang berlaku di abad ke tujuh ke abad ke dua puluh karena adanya perbedaan tingkat yang cukup tajam antara abad ke tujuh dan abad ke dua puluh (Mahmoud Mohamed Taha 1987, 18).

Ketika muncul persoalan-persoalan baru yang berbeda dengan persoalan yang dihadapi kaum muslimin pada masa Rasulullah SAW 
masih hidup, akibatnya umat Islam melakukan sebuah upaya yang disebut dengan ijtihad. Tentu saja dalam berijtihad harus berpedoman pada nash-nash al-Qur'an atau al-Hadits, sesuai dengan tuntutan kasus yang dihadapi. Peristiwa itu sering terjadi, karena kontak antara bangsa Arab dan bangsa-bangsa lain di luar jazirah Arab dengan corak budayanya yang beragam, segera menimbulkan berbagai kasus baru yang tidak terselesaikan dengan ditunjukkan oleh dhahir nash semata-mata, Sesungguhnya produk-produk pemikiran hukum Islam yang dihasilkan melalui ijtihad itu pada kenyataannya terikat oleh waktu dan kondisi ketika ijtihad itu dilakukan. Timbulnya penemuan-penemuan baru yang merubah sikap hidup dan menggeser cara pandang, membentuk pola alur berfikir, menimbulkan pula konsekuensi dan membentuk norma dalam hidup bermasyarakat. Terkait hal itu, bagi seorang muslim persoalan-persoalan baru yang muncul karena kemajuan iptek, tidak harus dihadapkan dengan ketentuan-ketentuan nash secara konfrontatif, tetapi harus dicari pemecahannya secara ijtihadi, karena realitas yang seringkali terjadi, bahwa perkembangan masyarakat lebih cepat daripada perkembangan yang ada dalam perkembangan hukum itu sendiri (Abd. Salam Arief 2003, 3).

Sejatinya tujuan dilaksanakan suatu hukum bertujuan untuk keamanan dan ketertiban dalam kehidupan bermasyarakat, begitu pula hukum Islam. Hukum Islam sebagaimana telah disepakati oleh para ulama adalah untuk mewujudkan kemaslahatan dan kebaikan hidup yang hakiki bagi manusia, baik secara individu maupun sosial. Al-Qur'ān sendiri sebagai sumber utama hukum Islam menyatakan sebagai petunjuk bagi seluruh umat manusia dan memerintahkan kepada manusia untuk taat kepada Allah dan Rasul-Nya. Perintah untuk mentaati kandungan al-Qur'ān termasuk aspek hukumnya harus dipahami sebagai ajaran yang bertujuan untuk kemaslahatan manusia baik di dunia maupun di akhirat, begitu pula perintah untuk mengikuti ajaran-ajaran syariah (M. Amin Abdullah 1996).

Sebenarnya sejak awal syariah Islam tidak memiliki tujuan lain kecuali kemaslahatan manusia. Adapun secara umum bahwa syariah Islam dicanangkan demi kebahagiaan manusia lahir batin serta duniawi ukhrawi, sepenuhnya mencerminkan prinsip kemaslahatan. Akan tetapi, 
pemahaman ortodoksi terhadap teks/nash terlalu berlebihan sehingga membuat pemahaman tersebut hanya bersifat jargon kosong (Mas'udi and Masdar 1995), kemudian problematika yang menjadi kesulitan respon hukum Islam adalah bagaimana hukum Islam ini harus bisa menyesuaikan tuntutan modernitas, yang ditawarkan oleh Abdullah Ahmed An-Na'im adalah melakukan dekontruksi syari'ah terhadap permasalahan isu-isu modernitas. Tujuanya adalah hukum Islam bisa menjadi sebuah solving problem berbagai persoalan dan permasalahan umat pada saat ini.

\section{Dekontruksi Syariah}

Kata Syariah secara etimologis berarti jalan ke tempat pengairan atau lalu air sungai (Ibn Manzhur 1990, 175) Manna' Khalīl Al-Qattan, mengartikannya syariah dengan sumber air yang dituju/didatangi untuk minum (Al-Qattan 1976, 9) Hasbi Ash-Shiddiqy mengartikan syariah adalah sebuah jalan yang dilalui air terjun (Ash-Shiddiqy and M. Hasbi 1978, 20). Muhammad Kamil Musa, mengartikan syariah, jalan tempat peminum mencari air (Musa Muhammad Kamil 1989, 17). Syari’ah juga diartikan sebagai jalan, aturan, ketentuan, atau undang-undang Allah SWT (Nurdin and Muslim K.H. 1995, 101).

Syariah dalam perspektif Islam merupakan hukum-hukum Allah yang terdapat dalam al-Qur'an dan as-Sunnah, syari'ah dalam pengertian ini adalah wahyu, baik dalam pengertian al-wahy al-mattū yang dalam hal ini adalah al-Qur'ān, maupun dalam pengertian al-wahy ghair almatlū yang dalm hal ini adalah as-Sunnah (Madkur 1955, 11). Syari'ah dapat dipahami sebagai ajaran Islam yang sama sekali tidak dicampuri oleh daya nalar manusia. Syari'ah merupakan wahyu Allah secara murni, karenanya ia bersifat mutlak, tetap, kekal, tidak bisa dan tidak boleh diubah. Dengan argumentasi ini, maka syariah merupakan sumber fiqh, karena fiqh merupakan pemahaman yang mendalam terhadap al-Nuŝûs al-Muqaddaṡah (nash-nash yang suci) tersebut (Husnul Khatimah $2007,1)$ terdapat dua dimensi dalam memahami hukum Islam. Pertama, hukum Islam berdimensi illahiyah, karena ia diyakini sebagai ajaran yang bersumber dari Yang Maha Sempurna dan Maha Benar. Dimensi ini hukum Islam oleh umat Islam dianggap sebagai ajaran suci, dan 
sakralitasnya selalu dijaga. Tataran ini hukum Islam dipahami sebagai syariah yang cakupannya begitu luas, tidak hanya terbatas pada fiqh dalam artian terminologi, tetapi juga mencakup bidang keyakinan, 'amaliyah, dan akhlak. Kedua, hukum Islam berdimensi insaniyah, dimensi ini hukum Islam merupakan upaya manusia secara sungguhsungguh untuk memahami ajaran yang dinilai suci dengan melakukan dua pendekatan, yaitu pendekatan kebahasaan dan pendekatan maqāsid. Dimensi ini hukum Islam dipahami sebagai produk pemikiran yang dilakukan dengan berbagai pendekatan, dikenal dengan sebutan ijtihad atau pada tingkat yang lebih teknis disebut istinbat al-ahkam (Juhaya S. Praja 2000).

Upaya dekonstruksi syariah dewasa ini tengah diupayakan oleh beberapa cendekiawan muslim. secara umum, hal ini didasari oleh asumsi bahwa bentuk syariah yang didasari oleh ushul fiqh klasik tidak lagi bisa mengakomodir kebutuhan umat Islam untuk bisa bersaing di era modern, asumsi seperti ini telah diadopsi oleh beberapa pakar keislaman Indonesia yang bergerak di dunia pendidikan ataupun yang bergerak di bidang hukum. Misalnya, adanya ketertarikan sebagian besar civitas UIN yang meyakini bahwa Hermeneutika adalah metodologi modern yang bisa menggantikan ushul figh yang telah usang (Yudian Wahyudi 2010).

Sebagai sebuah tindakan yang dilakukan si subyek, dia mesti melibatkan berbagai cara atau metode, yaitu metode subjek membongkar suatu objek yang patut dibongkar. Di situ mau tidak mau nama, Derrida harus disebut, karena dialah yang pertama kali membawa metode dekonstruksi ini di kancah filsafat secara sistematis. Dengan tersebutnya nama Derrida dan tercantumnya kata 'filsafat" dan "sistematis" nyatalah bahwa dekonstruksi bukan proses bongkar-membongkar yang sederhana, seperti pemahaman sehari-hari terhadap kata itu (Inyiak Ridwan Muzir 2006, 5-6). Dengan format hukum Islam yang unik yang terdapat dalam teks Ilahi yang konstan ini, syariat yang sudah baku yang ditetapkan oleh Allah SWT, serta melestarikan sifat ke-islaman (Islâmiyah) dan ketuhanan (Ilâhiyah) demi referensi dan sumber selamanya. Sedangkan perkara-perkara yang bersifat berubah (mutaghayyirât), diserahkan kepada fikih (pemahaman ulama) yang berkembang dan terus 
mengalami perubahan sesuai dengan perkembangan zamannya. Formasi Islam seperti inilah yang menempatkan nash yang dalam hal ini adalah al-Quran dan al-Hadits, dengan dinamika interpretasi manusia ter-hadap nash Mlahi yang konstan.

Istilah "Dekonstruksi Syari'ah" yang diperkenalkan oleh 'Abdullah Ahmed an-Na'im dalam mereformasi hukum Islam dapat dipahami sebagai sebuah cara baru yang sangat intoleran terhadap pembekuan dan pembakuan teks. Hal semacam ini seringkali dikategorikan sebagai tindakan subversif, sebab ada pembongkaran yang menembus ke dalam teks, untuk menampilkan watak arbitrer dan ambigu dari teks itu sendiri, yang senantiasa terkubur oleh kepentingan penulis dan pembaca teks. Hal ini biasanya dibangun untuk menciptakan kemapanan, padahal kemapanan (status quo) itu merupakan bagian dari kejumudan ini yang nanti pada akhirnya menjadi sebuah metode atau sebuah pendekatan yang disebut dekontruksi.

\section{Abdullah Ahmed An Naim}

Nama lengkap beliau adalah Abdullah Ahmed An-Na'im (Tholkhatul Khoir 2014, 111-12), lahir di Sudan pada tahun 1946. ia meyelesaikan pendidikan S1 di Universitas Khartoum Sudan dan mendapat gelar LL.B dengan ISLAMICA predikat cumlaude. Tiga tahun kemudian pada tahun 1973 An-Na'im mendapat tiga gelar sekaligus LL.B., LL.M., dan M.A. (diploma dalam bidang kriminologi) dari University of Cambridge, English. Pada tahun 1976, dia mendapat gelar Ph.D., dalam bidang hukum dari University of Edinburgh, Scotland, dengan disertasi tentang perbandingan prosedur prapercobaan kriminal (hukum Inggris, Skotlandia, Amerika, dan Sudan). Seperti halnya anak-anak kebanyakan di Negara -Negara Afrika, Abdullah Ahmed An-Na'im tidak dimanjakan oleh kemudahan fasilitas, seperti di Negara-negara maju. Dia hidup di bawah tempaan alam sehingga dia hidup dan tumbuh sebagai sosok yang berkarakter kuat, ulet, tegas, namun juga lembut dan bijaksana. Tepatnya menjelang awal tahun 1968, Abdullah Ahmed An-Na'im resmi menjadi anggota Persaudaraan Republik (yang kemudian menjadi partai Republik di tengah-tengah perjuangan Nasionalis Sudan pada akhir perang dunia II) dan Ia merupakan salah seorang generasi kontemporer 
dari sarjana aktivis muslim yang telah membina karir kesarjanaannya dengan keterlibatan dalam masalah-masalah sosial. Ia adalah pakar hukum international yang mendapat reputasi international karena terlibat dalam aksi-aksi penegakan Hak-Hak Asasi Manusia (HAM) di Sudan dan sekitarnya.

Setelah menyelesaikan pendidikan SMA-nya, Abdullah Ahmed AnNa'im kemudian melanjutkan ke Universitas Khartoum, Sudan, dengan konsentrasi Hukum Pidana (Imam Syaukani 1997, 68). Pada saat tercatat sebagai mahasiswa di Universitas, An-Na'im juga sempat berkenalan dengan seorang ulama moderat yang bernama Mahmud Muhammad Thaha (Mahmoud Mohamed Taha 1987, 2). Sejak mudanya dia sudah menggabungkan diri dengan partai Republican Brotherhood pimpinan Mahmud Muhammad Thaha, tokoh politik yang mati ditiang gantungan dieksekusi oleh pemerintahan Numeiri karena dituduh murtad. Salah satu karya terpentingnya adalah Toward an Islamic Reformation yang diterbitkan oleh Syracuse University Press, 1990. Ia menjadi profesor hukum di Thre the Emory Law School, Atlanta, Amerika Serikat. Selama 15 tahun terakhir dia menetap di AS.

Pada bulan November 1976 sampai Juni 1985, Abdullah Ahmed An-Na'im menjadi staf pengajar ilmu Hukum di Universitas Khartoum, Sudan. Pada tahun yang sama (1979-1985) An-Na’im menjadi ketua jurusan hukum publik di almamater yang sama. Pada bulan Agustus 1985-Juni 1992 Abdullah Ahmed An-Na'im menjadi profesor tamu Olof Palme di Fakultas Hukum, Universitas Upshala, Swedia. Pada bulan Juli 1992-1993 menjadi sarjana, tinggal di kantor The Ford Foundation untuk Timur Tengah dan Afrika Utara, di Kairo, Mesir. Pada bulan Juli 1993April 1995 menjadi Direktur Eksekutif Pengawas HAM di Washington D.C. Dan sejak Juni 1985 sampai sekarang menjadi profesor hukum di Universitas Emory, Atalanta, GA., Amerika Serikat. Tahun 1985-1987 bergabung dengan Associate Profesor of Law di Khartoum University dan menjadi Profesor of Law di UCLA. Sedangkan pada tahun 19881991 menjadi Ariel F. Sallow Profesor of Human Right di College of Law University of Saskatchewan di Canada. Sampai tahun 1992 menjadi Profesor Olof Palme pada University of Upshala Swedia. Tahun 1993 
dipercaya sebagai Direktur Eksekutif Africa Watch di Washington DC, sebuah lembaga pengamat Hak Asasi Manusia di Africa.

Karya ilmiah beliau Abdullah Ahmed An-Na'im adalah tentang dekontruksi syariah dalam bukunya yang berjudul Toward an Islamic reformation: Civil Libertis, human right and international Law, New york : Syracuse University press, 1990. Diterjemahkan oleh Ahmad Suaedy dan amirudin arrani, "Dekontruksi Syari'ah: Wacana Kebebasan Sipil, Hak Asasi Manusia dan Hubungan Internasional dalam Islam” (Abdullahi Ahmed An-Na'im 2004) yang membedah ambiguitas pemikiran hukum Islam baik persoalan metodologi maupun materinya. Tulisan An- Naim yang lain dapat ditemui dalam beberapa artikel dan makalahnya dalam bahasa Inggris di antaranya adalah : The Spirit of Ghost of Islamic Law, the Role of The Nation State in the 21th Century: Human Right, International Organization and Foreigh Policy. Dan Human Right, Religion and Secularism: Does it Have to be a Choice?

Buku tersebut memuat ide-ide Abdullahi Ahmed An-Na'im yang dimulai dengan pembahasan di sekitar konsep syari'ah yang berbeda dengan pemahaman umum. An-Na'im memahami syariah sebagai suatu konsep yang tidak bersifat Mlahiyyah (wahyu langsung dari Allah SWT), melainkan tidak lebih dari produk penafsiran dan penjabaran logis dari teks al-Qur'an dan as-Sunnah serta tradisi lainnya (Abdullahi Ahmed An-Na'im 2009). "Islam dan Negara Sekular: Menegoisasikan Masa Depan Syariah (2007), ini merupakan hasil penelitian kurang lebih 3 tahun (2004-2006), yang dilakukan dinegara turki, mesir, Sudan, Indonesia, Nigeria dan lain-lain. Dilihat dari karya beliau, Abdullah Ahmed AnNa'im termasuk ilmuan yang memiliki komitmen kuat terhadap Islam, perhatian utamanya adalah hukum Islam dalam kaitanya dengan isu-isu internasional, konstitusionalisme modern dan hukum pidana modern. Menurutnya, hukum Islam saat ini membutuhkan reformasi total atau rekontruksi menyeluruh.

Abdullah Ahmed An-Na'im berpendapat, negara-negara Barat telah dengan sangat baik mengartikulasikan konsep dan implikasi konstitusionalime, bukan berarti bahwa konsep konstitusionalisme Barat adalah yang ideal. Akan tetapi, prestasi Barat dalam membuat dan melaksanakan konsep konstitusionalisme perlu dihargai sebagai 
bagian dari keseluruhan pengalaman dan pe ngetahuan umat manusia, untuk kemudian diserap dan diadaptasi oleh umat Islam dan masyarakat lain dengan menyesuaikan agama dan tradisi kultural yang dimiliki (Abdullahi Ahmed An-Na’im 2009, 134).

\section{Pemikiran Abdullahi Ahmad An-Naim Tentang Syari’ah}

Pandangan Abdullah Ahmed An-Na'im terhadap al-Qurān adalah bahwa al-Qur'ān harus dipahami bukan sebagai kumpulan hukum atau bahkan buku hukum. Melainkan sesuatu yang memiliki daya tarik bagi umat manusia untuk mentaati hukum Tuhan yang telah lebih dahulu diwahyukan atau mungkin dapat ditemukan. Namun baginya, juga salah besar mengabaikan pengaruh al-Qur'an dalam penciptaan sistem perundang-undangan Islam. Di satu sisi benar bahwa hanya terdapat 500 ayat (atau 600 menurut sebagian ulama) dari seluruh ayat al-Qur'an berjumlah 6219 ayat yang mendukung elemen hukum, dan itu pun berkaitan dengan ibadah ritual. Hanya sekitar 80 ayat mengandung bahasa pokok tentang hukum dalam pengertian menggunakan istilahistilah hukum yang langsung dan jelas. Selebihnya menurut An-Naim merupakan ayat-ayat yang konstruksi sedemikian rupa, sehingga bermuatan dan berimplikasi hukum. Karena itu dapat dipastikan bahwa penggunaan al-Qurān sebagai sumber syari’ah tergantung pada perbedaan pandangan tentang relevansi dan interpretasi ayat-ayat (Abdullahi Ahmed An-Na'im 2009, 98).

Ketika Abdullah Ahmed An-Na'im mengatakan bahwa substansi hukum Islam sejalan dengan norma-norma legal HAM universal, dan dapat sejalan dengan berbagai kebutuhan masyarakat kontemporer dan standar-standar hukum internasional, ia mendasarkan pemikirannya pada prinsip resiprositas. Prinsip ini menyatakan bahwa harus memperlakukan orang lain sama seperti ia mengharapkan diperlakukan orang lain. Prinsip ini menurut Abdullah Ahmed An-Na'im dimiliki oleh semua tradisi agama besar dunia, termasuk Islam. Selain itu, prinsip ini menurutnya memiliki kekuatan moral dan logika yang dapat dengan mudah diapresiasi umat manusia (Abdullahi Ahmed An-Na'im 2009, 310). 
Al-Qur'an pada mulanya diwahyukan sebagai respon terhadap situasi masyarakat saat itu yang kemudian tumbuh dan berkembang lebih luas. Hukum-hukum yang terkandung di dalam al-Qur'an itu pun, masih ada yang memerlukan penafsiran dan mempunyai potensi untuk berkembang. Jika pada masa Rasulullah SAW, dalam memahami ayatayat semacam itu dan problematika-problematika, penjelasan diberikan langsung oleh Beliau dengan sunnahnya dan para shahabat melihat langsung jawaban yang diberikan oleh Rasulullah. Akan tetapi, pada masa berikutnya masa setelah Rasulullah, ketika beliau sudah wafat dan masyarakat Islam mengalami perkembangan pesat, serta wilayah kekuasaan Islam semakin luas, penjelasan itu dilakukan oleh para sahabat melalui pengalaman dan penglihatan selama hidup bersama dengan Rasulullah. Tanggung jawab ini terus berlanjut dan beralih kepada para tokoh atau ulama' mujtahid dari generasi berikutnya.

Istilah "Dekonstruksi Syariah” yang diperkenalkan oleh 'Abdullahi Ahmad an-Na'im dalam mereformasi hukum Islam dapat dipahami sebagai sebuah cara baru yang sangat intoleran terhadap pembekuan dan pembakuan teks. Hal semacam ini seringkali dikategorikan sebagai tindakan subversif, sebab ada pembongkaran yang menembus ke dalam teks, untuk menampilkan watak arbitrer dan ambigu dari teks itu sendiri, yang senantiasa terkubur oleh "kepentingan" penulis dan pembaca teks. Hal ini biasanya dibangun untuk menciptakan kemapanan, padahal kemapanan (status quo) itu merupakan bagian dari kejumudan (Lahmuddin Nasution 2001, 5).

Abdullahi Ahmad an-Na'im menurutnya umat Islam sedunia boleh saja (berhak) menerapkan hukum Islam, asal tidak melanggar hak orang dan kelompok lain, baik di dalam maupun di luar komunitas Islam. Artinya, dalam mengklaim dan menggunakan hak-hak perorangan dan kolektif untuk menentukan nasib sendiri, kaum muslimin juga harus mengakui dan menjamin hak-hak yang sama bagi orang lain. Persoalannya, menurut Abdullahi Ahmad an-Na'im, jika syariat historis (Abdullahi Ahmad an-Na'im menggunakan istilah historical shariah untuk menamakan syariat Islam) diterapkan sekarang, akan menimbulkan masalah serius menyangkut masalah-masalah konstitusionalisme, hukum pidana, hubungan internasional dan hak-hak asasi manusia. 
Menurutnya, yang paling merasakan akibatnya adalah masyarakat nonmuslim dan kaum wanita. Bagi masyarakat non-muslim mereka akan menjadi masyarakat kelas dua dengan status dzimmi, dan bagi wanita, mereka akan kehilangan kesempatan untuk memperoleh pendidikan dan minimnya akses ke dalam kehidupan publik. Bahkan kaum laki-laki pun, katanya, juga akan merasakan dampaknya, yaitu mereka akan kehilangan kebebasan karena disekat berbagai undang-undang. Abdullahi Ahmad an-Na'im menyatakan, kasus ini banyak terjadi di negara kelahirannya, Sudan (Abdullahi Ahmed An-Na'im 2009, 11): Abdullahi Ahmad anNa'im memaparkan :

"menganggap ada bagian Syari'ah yang tidak memadai, akan dituduh bid'ah oleh mayoritas umat Islam yang meyakini bahwa keseluruhan syari'ah itu bersifat Ilahiyah. Pandangan yang menjadi keyakinan umum ini akan menjadi hambatan psikologis utama dalam upaya merekonstruksi syariah, apalagi diperkuat dengan ancaman tuntutan hukum pidana dengan dakwaan murtad (apostasy). Ini adalah ancaman nyata di negara-negara Islam seperti Sudan dewasa ini".

Seperti halnya yang dialami banyak Negara di dunia, pengalaman sejarah Sudan di masa lalu juga tak lepas dari cengkraman kolonialisme. Negeri ini pertama kali mengalami penjajahan dari bangsa Turki-Mesir pada tahun 1821 (Abdullahi Ahmed An-Na'im 2004, 206). Untuk mengatasi persoalan tersebut, Abdullahi Ahmad an-Na'im mengajukan konsep perubahan dalam hukum publik di Negara-negara Islam dengan membangun suatu versi hukum publik Islam yang sesuai dengan standar konstitusionalisme, hukum pidana, hukum internasional dan hak-hak asasi manusia modern. Untuk tujuan itu, Abdullahi Ahmad an-Na'im menafikan kesakralan syari'at, karena syari'at bukanlah bersifat ilahiyyah (wahyu yang langsung dari Allah SWT). Syariat, menurutnya, adalah hasil dari proses penafsiran, derivasi melalui qiyas terhadap teks al-Qur'an, as-Sunnah, dan tradisi yang lain. Formulasi syariah, sebagaimana sistem perundang-undangan lainnya, mengikuti tahap-tahap perkembangan umat. Katanya, teknik-teknik penjabaran syariat dari sumber sucinya dan cara-cara penyusunan konsep dan prinsip fundamentalnya, jelas merupakan produk proses sejarah intelektual, sosial, dan politik umat Islam (Abdullahi Ahmed An-Na’im 2004, 14). 
Abdullahi Ahmad an-Na'im membagi tipe pembaharuan hukum yang banyak dikembangkan oleh bangsa-bangsa muslim pada umumnya : pertama Takhsi al-Qadha (hak penguasa untuk memutuskan dan menguatkan keputusan pengadilan) digunakan untuk membatasi penerapan syari'ah pada persoalan-persoalan perdata bagi umat Islam. Kedua Takhayyur (menyeleksi berbagai pendapat didalam madzhab fiqih tertentu dan tidak memilih pendapat dominan didalam madzhab arus pertama, melihat madzhab yang dominan adalah madzhab hanafi, yang merupakan madzhab resmi bagi masalah-masalah yang berkaitan dengan hukum perdata umat Islam. Ketiga Siyasah syari'ah (kebijaksanaan penguasa untuk menerapkan aturan-aturan administratif yang bermanfaat dan tidak bertentangan dengan syari'ah juga digunakan untuk memperkenalkan berbagai bentuk pembaharuan, kemudian Penafsiran kembali terhadap hukum perdata, untuk membatasi maraknya perceraian

\section{Pisau Analisis Abdullahi Ahmed An-Nai'm}

\section{a. Teori Evolusi Hukum Mahmud Thaha}

Metodologi yang digunakan oleh Abdullahi Ahmad an-Na'im sebenarnya tidak akan terlepas dari gagasan-gagasan pembaharuan yang diusung oleh gurunya Mahmoud Muhammad Thaha. Oleh karena itu, berbicara mengenai kecenderungan pemikiran Abdullahi Ahmad anNa'im, terutama mengenai konsep dasar reformasi syariah, tidak bisa melewatkan metodologi pembaharuan yang disebut dengan evolusi legislasi yang digagas oleh Mahmoud Muhammad Thaha sebelumnya.

Orang Arab sendiri menggunakan istilah ini khususnya dengan "jalan setapak menuju sumber air yang tetap dan diberi tanda yang jelas, sehingga tampak oleh mata” penggunaan hermeneutika Abdullahi Ahmad an-Na'im telah menghasilkan sebuah pendekatan baru yang disebutnya dengan 'Evolutionary Approach', sebuah pendekatan yang dikembangkan oleh gurunya Mahmud Muhammad Taha dalam bukunya Al-Risalah al-Tsaniyah. Esensi pendekatan ini adalah sanggup menyingkirkan teks-teks al-Qur'an dan as-Sunnah. Madinah yang jelas dan definitif karena mereka telah melaksanakan fungsi transisinya, dan 
selanjutnya mengimplementasikan teks-teks periode Mekkah yang sebelumnya tidak sesuai untuk tujuan aplikasi praktis.

Demikian pula dalam Islam, bahwa hukum Islam memiliki corak tersendiri bila dihadapkan pada realitas sosial. Gagasan mengenai Islam sebagai asas negara biasa diekspresikan dengan kata fiqh (fikih) dan syariah (syariat). Fikih, secara orisinal bermakna dalam pengertian yang luas. Seluruh upaya untuk mengelaborasi rincian hukum ke dalam norma-norma spesifik negara, menjustifikasinya dengan perujukan kepada wahyu, mendebatkannya, atau menulis kitab dan risalah tentang hukum merupakan contoh-contoh Fikih. Sebaliknya, syariah merujuk kepada hukum-hukum Tuhan dalam kualitasnya sebagai wahyu. Dalam penggunaan yang longgar, syariah bisa menunjuk kepada Islam sebagai Agama Tuhan. Akan tetapi, kata syariah sering digunakan sebagai pengganti dari kata Fikih, dimana konotasi kata tersebut menjadi tradisi keserjanaan Hukum Islam.

Abdullahi Ahmad an-Na'im mengambil metode dari gurunya, yaitu menggunakan metodologi pembaharuan yang revolusioner, yang digambarkan sebagai evolusi legislasi Islam (modern mistical approach), adalah suatu ajakan untuk membangun prinsip penafsiran baru yang memperbolehkan penerapan ayat-ayat al-Qur'an dan as-Sunnah. Pendekatan ini jika diterapkan akan mampu memecahkan kebuntuan antara tujuan pembaruan, keterbatasan konsep dan teknik syariah historis. Mengutip pendapat ustadz Mahmoud Muhammad Thaha pendekatan evolusinya syariah berkaitan dengan prinsip interpretasi. "evolusi syari'ah adalah evolusi dengan perpindahan dari suatu teks (al-Qur'an) ke teks lain. Dari suatu teks yang pantas untuk mengatur abad ke tujuh dan telah diterapkan kepada teks yang pada waktu itu telah mandul dan oleh karena itu dibatalkan. Jika ayat tambahan, yang digunakan menolak ayat utama pada abad ketujuh telah menfungsikan tujuannya secara sempurna dan menjadi tidak relevan bagi abad kedua puluh, kemudian waktu telah memungkinkan menghapuskannya dan memberlakukan ayat utama. Ayat utama caranya kembali sebagai teks yang operatif pada abad ke dua puluh dan menjadi basis legislasi yang baru. Inilah yang dimaksud dengan evolusi syariah (Mahmoud Mohamed Taha 1987, 40-41). 
Sesuai dengan logika prinsip evolusioner yang diajukan oleh Ustadz Mahmoud Muhammad Thaha, teks-teks al-Qur'ān yang menekankan solidaritas umat Islam secara ekslusif diwahyukan selama masa Madinah untuk memberikan kepada masyarakat muslim yang sedang menumbuhkan kepercayaan psikologis dalam berhadapan dengan serangan non muslim. Kebalikan dari ayat-ayat tersebut pesan Islam yang fundamental dan abadi seperti yang diwahyukan al-Qurān periode Mekkah, mengajukan solidaritas seluruh umat manusia. Dalam kebutuhan vital bagi prinsip hidup berdampingan secara damai dalam masyarakat global ini, umat Islam harus menekankan pesan-pesan abadi solidaritas universal Mekkah dari pada solidaritas ekslusif pesan tradisional Madinah (Abdullahi Ahmed An-Na’im 2009, 335-36).

\section{1) Teori nasikh mansukh}

An-Naim menyebutkan kesulitan utama yang dihadapi hukum Islam ketika berhadapan dengan isu-isu HAM universal adalah kerangka acuan (frame of referenced) yang telah dimilikinya (Abdullahi Ahmed An-Na'im 2004, 309). Prinsip nāskh pembatalan teks al-Qur'an dan Sunnah tertentu untuk tujuan-tujuan penetapan hukum oleh teks-teks al-Qur'an dan Sunnah untuk validitas teoritik dan kelangsungan praktek dari pendekatan evolusioner. Kemudian memadukan teori nasakh tersebut dengan prinsip-prinsip umum tentang analisa kongkret terhadap implikasiimplikasi hukum publik Islam. Utamanya terhadap keseimbangan hak-hak muslim dan non-muslim serta laki-laki dan perempuan dalam menentukan nasib sendiri. Inilah harga kemanusian yang tertimbun dalam formulasi teoritik syariah tradisional (Abdullahi Ahmed AnNa'im 2004, 69-70), Pemahan an-Na'im terhadap konsep naskh berbeda dengan apa yang telah berlaku dalam literatur yurisprudensi Islam. Hal ini didasarkan ayat nāskh $(2: 106)$ yang diterjemahkan Taha sebagai berikut: "Ayat yang kami nāskh (menghapuskan hukum suatu ayat) atau yang Kami tunda pelaksanaan hukumnya, maka Kami gantikan dengan ayat yang lebih dekat dengan pemahaman manusia, atau memulihkan berlakunya ayat itu pada saat yang tepat" (Abdullahi Ahmed An-Na'im 2004, 104).

Kepentingan khusus pada konteks masa sekarang ini adalah mempertimbangkan kembali prinsip nāskh (pembatalan atau 
pencabutan berlakunya hukum ayat-ayat al-Qur'an tertentu, digantikan dengan ayat-ayat yang lain (Abdullahi Ahmed An-Na'im 2004). Teori nāskh sebagaimana yang dipahami Taha mengatakan bahwa suatu teks atau ayat akan di elaborasi karena tidak lagi sesuai dengan situasi zaman, dan selanjutnya akan diganti dengan ayat yang lebih sesuai yaitu ayatayat pada periode Mekkah. Isu hukum publik memperhatikan pada awal abad kedua puluh, maka perlu mengedepankan sebuah pendekatan evolusi yang berbasis hukum Islam dari teks Madinah ke teks Mekkah yang lebih awal. Dengan kata lain prinsip interpretasi yang evolusioner tidak lain adalah dengan cara membalikkan proses nāskh, sehingga teks-teks yang dihapus pada masa lalu dapat digunakan dalam hukum sekarang dengan konsekuensi penghapusan teks yang dulu digunakan sebagai basis pembentukan syari'ah

Rukun-rukun nāskh ada empat, yaitu: pertama Adat al-nāskh, yaitu pernyataan yang menunjukkan pembatalan (penghapusan) berlakunya hukum yang telah ada. Kedua Näsikh, yaitu Allah Ta’ala, karena Dialah yang membuat hukum dan Dia pula yang membatalkannya sesuai dengan kehendak-Nya. Ketiga Mansūkh, yaitu hukum yang dibatalkan, dihapuskan atau dipindahkan. Keempat Mansūkh 'anh, yaitu orang yang dibebani hukum

\section{2) Makiyyah dan Madaniyah}

Abdullahi Ahmad an-Na'im membagi al-Qurān ke dalam dua corak pesan yang secara kualitatif berbeda, yaitu pesat pada ayat-ayat Mekkah dan pesan pada ayat Madinah Substansi dari pesan Mekkah menekankan pada nilai-nilai keadilan dan persamaan fundamental serta martabat melekat pada seluruh umat manusia. Sementara itu pembaharuan isi pesan setelah ia hijrah ke Madinah adalah al-Qur'ān dan Sunnah yang menyertainya nilai membedakan antara laki-laki dan perempuan muslim dan non muslim dalam status hukum dan hak mereka di depan hukum. Lebih tegas lagi An-Naim mengungkapkan bahwa semua ayat dan Sunnah yang terkait menjadi dasar diskriminasi terhadap perempuan dan non muslim merupakan ayat-ayat Madinah. Menurutnya teks alQur'ān periode Mekkah dan Madinah berbeda, bukan karena waktu dan tempat pewahyuannya, melainkan sebenarnya karena perbedaan kelompok sasarannya. Kata-kata "wahai orang yang beriman" sering 
digunakan dalam ayat-ayat Madinah menyapa bangsa tertentu. Katakata "wahai manusia" dalam ayat-ayat Mekkah berbicara pada semua manusia. (Abdullahi Ahmed An-Na’im 2009, 126).

Pertama, dari perspektif masa turun, Makkiyah adalah ayat-ayat yang diturunkan sebelum Rasulullah hijrah ke Madinah, sekalipun tidak turun di Mekkah, dan Madaniyah adalah ayat-ayat yang diturunkan setelah Rasulullah hijrah ke Madinah, sekalipun tidak turun di Madinah, seperti surah al-Nisa' 4:58 termasuk kategori Madaniyyah kendati turunnya di Mekkah, yaitu pada peristiwa Fath al-Makkah yang terjadi setelah hijrah.

Kedua, dari perspektif tempat turun, Makkiyah adalah ayat-ayat yang diturunkan di Mekkah dan sekitarnya seperti Mina, Arafah, dan Hudaibiyah sekalipun itu terjadi setelah hijrah, kemudian Madaniyah adalah ayat-ayat yang diturunkan di Madinah dan sekitarnya seperti Uhud, Quba, dan Sul'a, Surat Makkah lebih memperhatikan masalah spiritual dan cakrawala keagamaan, sedang surat Madinah problem politik, sosial dan hukum menjadi lebih ditekankan. Abdullahi Ahmad an-Na'im memahami konsep Makkiyah dan Madaniyah dengan pandangan yang berbeda dengan jumhur ulama. Ayat-ayat Makkiyyah dan ayat-ayat Madaniyyah merupakan dua paket (tahapan) yang terpisah, yang satu dengan yang lain tidak saling terkait. Ia berbeda bukan saja terkait perbedaan masa turunnya, tetapi juga terkait dengan perbedaan tema dan misi yang dibawa, sasaran (khitab)-nya, dan watak universalnya. An-Na'im menyimpulkan bahwa ayat-ayat Makkiyyah membawa tema dan misi yang fundamental dan abadi, ia berbicara kepada semua manusia tanpa diskriminasi, melintasi batas dimensi waktu dan tempat. Sedangkan ayat-ayat Madaniyyah membawa misi sementara, diturunkan untuk masyarakat tertentu sesuai dengan kondisi manusia abad VII sehingga tidak bisa difungsikan lagi pada saat ini. Selanjutnya dengan menggunakan konsep naskh, ia melakukan generalisasi, ayat-ayat Makkiyyah me-nāskh ayat-ayat Madaniyyah.

Bahkan Abdullahi Ahmad an-Na'im tetap bersiteguh pada proposisi bahwa hukum publik di negara - negara Muslim tetap didasarkan pada hukum Islam (Ann Elizabeth Mayer 1996, 42-43). Prinsip dan aturan dalam Al-Qur'an dan hadits sendiri banyak yang problematika dalam 
konteks system dan nilai hukum publik modern (Ann Elizabeth Mayer 1996, 83). Meskipun tidak sepenuhnya menekankan pada pembenaran historis, menurut An-Naim, masyarakat dapat melihat kecukupan historis berbagai pembenaran yang dapat ditawarkan berkaitan dengan persoalan diskriminasi di atas, dilihat dari sudut pandang ekonomi maupun politik. Akan tetapi bagi An-Naim, dengan mengabaikan berbagai perbedaan tentang kecukupan pembenaran-pembenaran historis, berbagai masalah diskriminasi terhadap perempuan dan non-Muslim di bawah payung hukum Islam tidak lagi dapat dibenarkan. Diskriminasi atas dasar agama dan gender di bawah payung hukum Islam tersebut jelas melanggar penegakkan HAM universal. Diskrimasi yang mendasarkan baik gender maupun agama secara moral dan politik tidak dapat diterima (Abdullahi Ahmed An-Na'im 2004, 335). Diksriminasi atas dasar gender dan agama adalah titik konflik paling serius yang dihadapi hukum Islam. Abdullahi Ahmad an-Na'im menerapkan metode rekonsiliasinya, Rekonsiliasi menurut An-Naim hanya dapat dicapai melalui pembaruan hukum Islam secara radikal (Abdullahi Ahmed An-Na'im 2004, 339-40).

3) Pemaknaan teks berbasis gender

Banyak terjadi bias gender dalam pemaknaan terhadap teks-teks suci keagamaan baik teks Al-Quran maupun al-Hadits. Misalnya pemaknaan yang berujung menempatkan perempuan sebagai subordinasi lakilaki. Semua itu terjadi dalam konteks pemaknaan. Islam jelas telah membebaskan manusia dari segala bentuk penindasan dan perbudakan terhadap sesama manusia. Firman Allah Swt. Q.s. al-Hujurât ayat 13: Dengan mengakui penghambaan hanya kepada-Nya, maka semua manusia, setara (egaliter) dihadapan-Nya, yang membedakan tingkat ketakwaannya. Contoh lainnya, adalah hukum waris, Pada masa praIslam, perempuan sama sekali tidak mendapat waris. Ketika Islam datang, perempuan mendapat, kendati satu banding dua. Jadi, al-Quran memang diturunkan sebagai respon untuk mengangkat martabat perempuan, laki-laki dan perempuan diciptakan oleh Allah SWT. yaitu untuk mengabdi kepada-Nya. Laki-laki perempuan punya potensi dan peluang yang sama.

Mengapa dalam tataran kenyataan, hingga kini, ketidakadilan tetap saja selalu melekat pada perempuan? konstruksi laki-laki itu, 
lantas mempengaruhi produk-produk pemikiran keagamaan, baik tafsir maupun fiqih. "Karenanya, teks yang terkesan bias gender itu harus dimaknai sesuai konteks zamannya. Al-Quran itu terdiri dari universal (kulliyât) dan partikular (juz'iyyât) yang butuh penjelasan kontekstual.

Pendekatan tekstual terhadap ayat-ayat Alquran mesti diwaspadai karena mempunyai kecenderungan mengabaikan spirit pemberdayaan pada seluruh ayat-ayat yang berkaitan dengan gender. Muhammad Abduh mensinyalir sebagian besar kata-kata Alquran telah berubah kandungan maknanya bahkan pada masa dekat setelah turunnya (Forum Kajian Kitab Kuning 2001, 94).

Konsep syariah terhadap Hak Asasi Manusia (HAM)

Berdasarkan metodologi itu, pertama-tama Abdullahi Ahmad anNa'im memulai dengan melakukan otokritik terhadap syari'ah. Selama ini menurut beliau syariah oleh mayoritas umat Islam telah dipahami sebagai formulasi final dari hukum Tuhan, karena itu keadaan dan kondisi syariah menjadi absolut, rigid dan anti perubahan (Asghar Ali al Enginer 1994, 9-10). Pendekatan yang digunakan Abdullahi Ahmad anNa'im memahami hak asasi manusia universal dan adaptasi sejarah ketika berhadapan dengan realitas dunia modern, terutama tentang penerapan syariah dalam hukum publik (konstitusionalisme, hukum pidana, hak asasi manusia dan hukum internasional adalah hermeneutika) (Abdullahi Ahmed An-Na’im 2004, 229-42).

Kebutuhan akan reformasi Syari'ah dan perangkat metodologinya didasarkan pada anggapan bahwa posisi dan formulasi Syariah yang ada dianggap sudah tidak memadai lagi dan bahkan dinilai bertentangan dengan prinsip-prinsip hukum modern dan hak-hak asasi manusia (HAM) yang menjadi isu, Dari sini muncul tuntutan untuk membangun model Syariah yang sesuai dengan standar hukum publik modern, khususnya berkenaan dengan HAM. Bersamaan dengan itu, kaum muslimin dihadapkan pada pilihan dilematis antara keharusan melaksanakan Syariah sebagai kewajiban keagamaan, dengan mentaati HAM sebagai tuntutan masyarakat internasional; antara keinginan menjunjung tinggi nilai-nilai ajaran Islam yang sudah teraktualisasi dalam tradisi mereka, dengan kebutuhan mengikuti gagasan-gagasan modern. Berpegang teguh pada pada warisan tradisi masa lalu berarti 
mengabadikan keterbelakangan, sementara meninggalkannya sama sekali mungkin akan menghancurkan identitas Islam dan seluruh bangunan emosional dan intelektual yang telah diwarisi dan dianut selama ini.

Abdullahi Ahmad an-Na'im menyebutkan, jika syariat historis diterapkan sekarang, akan menimbulkan masalah yang serius menyangkut masalah-masalah konstitusionalisme, hukum pidana, hubungan internasional dan hak-hak asasi manusia, yang paling merasakan akibatnya adalah masyarakat non-muslim dan kaum wanita (Abdullahi Ahmed An-Na'im 2009, 8-9). Pengaruh kebudayaan Barat sangat menentukan terhadap eksistensi deklarasi HAM 1948 dan juga terhadap formulasi lebih lanjut dari kovenan HAM International merupakan fakta yang tak bisa dibantah. Kesadaran terhadap hal tersebut telah mengakibatkan konflik idiologis dalam wacana International tentang HAM. Konflik itu meliputi tantangan terhadap penerapan HAM universal dan penolakan terhadap pemahaman bahwa norma-norma HAM dapat (atau sebaliknya) dipahami sebagai standar yang tidak mengenal batas waktu dan perbedaan kebangsaan di seluruh dunia. Tantangan dan penolakan tersebut seiring beberapa klaim tentang perbedaan dan relativisme seputar tradisi-tradisi filosofis, religius dan kultur tertentu (Abdullahi Ahmed An-Na'im 2009, 75). Adanya keragaman ketentuan dalam al-Qur'an diasumsikan oleh para ulama sebagai akibat logis adanya pentahapan dalam penetapan hukum. Ketentuan-ketentuan hukum yang diterapkan tentunya tidak mungkin begitu saja akan diterima tanpa adanya proses pembelajaran dan penyadaran secara gradual.

\section{Kesimpulan}

Abdullahi Ahmed an-Na'im yang lebih dikenal dengan Na'im, lahir di Sudan, 1946, menyelesaikan pendidikan SI di Universitas Khartoum, Sudan dan mendapat gelar LL.B dengan predikat cumlaude. Kemudian mendapatkan tiga gelar sekaligus yaitu LL.B., LL.M., dan M.A dari University of Cambridge English. Pada tahun 1976, ia mendapat Ph.D dengan disertasi tentang perbandingan prosedur prapercobaan kriminal (hukum Inggris, Skotlandia, Amerika, dan Sudan). Perjalanan kariernya, Na'im kemudian lebih dikenal sebagai ahli itu hukum dan aktivis hak asasi manusia (HAM) di Washington D.C,. Ia adalah murid utama 
Mahmoud Mohamed Thaha, seorang pembaharu Islam, dan pernah mengajar di sekolah hukum di Sudan, Kanada, dan Amerika Serikat. Abdullahi Ahmad an-Na'im banyak menerjemahkan buku gurunya tersebut ke dalam bahasa Inggris. Sumbangan pemikiran Na'im lebih terfokus pada penyelarasan penafsiran Islam Mahmoud Mohamed Taha dengan gagasan-gagasan Barat tentang HAM.Dalam membedah permasalahan upaya pembaharuan hukum Islam dalam sejarah, dalam

Dekonstruksi Syari'ah, Abdullahi Ahmad an-Na'im meminjam teori yang Jhon O. Voll tentang kategorisasi kecenderungan pembaharuan hukum Islam. Abdullahi Ahmad an-Na'im berhasil mengurai masalahmasalah dan kebuntuan-kebuntuan legislasi Syari'ah dalam konteks perkembangan hukum kontemporer, khususnya masalah kesetaraan gender dan HAM. selanjutnya, pendekatan yang digunakan Abdullahi Ahmad an-Na'im untuk menyelesaikan masalah kebuntuan legislasi itu adalah antropologis-historis yang dielaborasikan dengan konsep Nāsakh dan Makki-Madani.

Metodologi Abdullahi Ahmad an-Na'im sebenarnya tidak akan terlepas dari gagasan-gagasan pembaharuan yang diusung oleh gurunya Mahmoud Muhammad Thaha oleh karena itu ketika berbicara tentang hal yang berkait dengan pemikiran an-Naim, terutama mengenai konsep dasar reformasi syariah, tidak bisa melewatkan metodologi pembaharuan yang disebut dengan evolusi legislasi yang pernah digagas oleh Thaha sebelumnya, bisa dikatakan metode yang digunakan Abdullah Ahmad an-Na'im ini adalah Islam liberal. 


\section{DAFTAR PUSTAKA}

Abd. Salam Arief. 2003. Pembaruan Pemikiran Hukum Islam. Yogyakarta: LESFI.

Abdullahi Ahmed An-Na'im. 2004. Dekonstruksi Syariah (Jilid 1); Wacana Kebebasan Sipil, HAM Dan Hubungan Internasional Dalam Islam. Yogyakarta: LKiS.

_—_. 2009. Dekonstruksi Syariah (Jilid 2) ; Kritik Konsep, Penjelajahan Lain. Yogyakarta: LKiS.

Al-Qattan. 1976. Manna' Khalïl, At-Tasyri' Wa Al-Fiqh Al-Islam. Makkah: Maktabah Wahbah.

Ann Elizabeth Mayer. 1996. Ambiguitas An-Naim Dan Hukum Pidana Islam", Dalam Dekonstruksi Syariah (II). ed. Farid Wajidi. Yohyakarta: LKiS.

Asghar Ali al Enginer. 1994. The Right of Human in Islam, Alih Bahasa Bentang. Yogyakarta: Bentang.

Ash-Shiddiqy, and M. Hasbi. 1978. Pengantar Ilmu Fiqh. Jakarta: Bulan Bintang.

Forum Kajian Kitab Kuning. 2001. Wajah Baru Relasi Suami-Istri. Yogyakarta: LKiS.

Husnul Khatimah. 2007. Penerapan Syariah Islam: Bercermin Pada Sistem Aplikasi Syari'ah Zaman Nabi. Yogyakarta: Pustaka Pelajar.

Ibn Manzhur. 1990. Lisan Al-Arab. Beirut: Dar al-Fikr.

Imam Syaukani. 1997. "Abdullahi Ahmad An-Na'im Dan Reformasi Syari'ah Islam Demokratik.” Ulumuddin 2.

Inyiak Ridwan Muzir. 2006. Pengantar Penerjemah: Dekonstruksi: Sebuah Perkenalan Singkat "Membongkar Teori Dekonstruksi Jacques Derrida." Yogyakarta: Ar-Ruzz Media.

Juhaya S. Praja. 2000. Dinamika Pemikiran Hukum Islam, Dalam Jaih Mubarok, Sejarah Dan Perkembangan Hukum Islam. Bandung: Remaja Rosda Karya. 
Lahmuddin Nasution. 2001. Pembaruan Hukum Islam. Bandung: Rosdakarya.

M. Amin Abdullah. 1996. Studi Agama Normativitas Atau Historisitas. Yogyakarta: Pustaka Pelajar.

Madkur, Muhammad Sallam. 1955. Al-Fiqh Al-Islami. Makkah: Maktabah Abdullah Wahbah.

Mahmoud Mohamed Taha. 1987. The Second Message of Islam. New York: Syracuse University Press.

Mas'udi, and F. Masdar. 1995. "Meletakkan Kembali Maslahat Sebagai Acuan Syariah." Jurnal Ilmu dan Kebudayaan, Ulumul Qur'an VI(3).

Musa Muhammad Kamil. 1989. Al-Madkhal Ila Al-Tasyrī’ Al-Islami. Beirut: Mua'asasah al-Risalah.

Nurdin, and Muslim K.H. 1995. Moral Dan Kognisi Islam (Buku Teks Agama Islam Untuk Perguruan Tinggi Umum). Bandung: CV. ALFABETA.

Tholkhatul Khoir. 2014. "Determinasi Eksistensial Pemikiran Hukum Islam Abdullahi Ahmed An-Naim.” ISLAMICA: Jurnal Studi Keislaman 9(1).

Yudian Wahyudi. 2010. Ushul Fikih Versus Hermeneutika; Membaca Islam Dari Kanada Dan Amerika. Yogyakarta: Nawasea Press. 